\title{
VEGETATION ANALYSIS OF SOME WETLAND HABITATS IN CENTRAL REGION OF SAUDI ARABIA
}

\author{
Al-AMro, A. M.* - EL-SHEIKH, M. A. - El-SHEIKH, A. M. \\ Botany and Microbiology Department, College of Science, King Saud University \\ P.O. Box 2455, Riyadh 11451, Saudi Arabia \\ *Corresponding author \\ e-mail: amro200518@gmail.com \\ (Received $17^{\text {th }}$ Feb 2018; accepted $30^{\text {th }}$ May 2018)
}

\begin{abstract}
In this study, the vegetation of 63 sabkha and sewage canals in central region of Saudi Arabia was analyzed. A total of 109 plant species belonging to 83 different genera and 34 different plant families were collected. The most common plant families were Chenopodiaceae (18 species), Poaceae (16 species) and Asteraceae (10 species). Vegetation in the study area was classified into 6 groups; two of them were found in sabkhas only, one was found in sewage canals only and the other three were found in both habitats. The main factors controlling the plant presence and vigour in the studied wetlands were soil salinity, $\mathrm{pH}, \mathrm{EC}$, soil texture and content of organic matter.
\end{abstract}

Keywords: wetlands, vegetation, DECORANA, TWINSPAN

\section{Introduction}

Wetlands are defined as the areas that are inundated or saturated by surface or groundwater at a frequency and duration sufficient to support a prevalence of vegetation typically adapted for life in saturated soil conditions (LePage, 2011). They include, for example, salt marshes (sabkhas), shallow ponds and sewage canals. Wetlands are identified by unique soils (hydric soils), plants adapted to life in wet environments (hydrophytes) and the presence of water (hydrology) during the growing season. From an ecological perspective, wetlands are simply a particular slice of the continuum between the wettest ecosystem types (rivers, lakes, estuaries, and the marine environment) and the driest environments within a physiographic (broad-scale subdivisions of the Earth's surface based on terrain texture, rock type, geologic structure, and history) region (Brinson, 2011).

Wetlands in the central region of Saudi Arabia are considered among the main diverse habitats. However, there have been no studies of their vegetation diversity until now. In Saudi Arabia, wetlands are located in a hot and dry region that is experiencing major climate changes. They are generally characterized by high biodiversity in terms of both animals and plants. With their hydrologic characteristics, wetlands have a great ecological importance. They have plants with high productivity and provide habitats for many wild fishes and birds (LePage, 2011). Saudi Arabia has several natural and industrial wetlands including lakes, sabkhas and wadis. Beside their importance to various animals especially amphibians, wetland habitats have a great potential to conserve biodiversity of plants (Flinn et al., 2008). Al-Obaid et al. (2017) stated that wetlands are also of great economic importance in agriculture and grazing. Nevertheless, the plant communities of different wetlands in Saudi Arabia has not been fully described. The aim of this study was to characterize the vegetation of different wetlands in central region of Saudi Arabia. 


\section{Materials and methods}

\section{Study area}

The central "Najd" region is the large central plateau in Saudi Arabia; it is divided into two parts: the higher Najd in the west (located on the Arabian Shield region) and the lower Najd in the east. The altitude in this area ranges from $500-1000 \mathrm{~m}$ above sea level. The higher Najd is characterized by an extensive system of large wadis. Wadis in general flow from west to east, following the slope of the land, from the higher mountains in the west to the lower plains of Najd.

Qassim is located in the northern central region of Saudi Arabia with an area of $80.000 \mathrm{~km}^{2}$. It has two different geological regions; one is located on the Arabian Shield region and the other is located in the sedimentary sector (the Arabian Shelf). Qassim has many sabkhas and wadis in addition to several mountains. Riyadh is located at $24^{\circ} 38^{\prime}$ $\mathrm{N}$ lat. and $46^{\circ} 43^{\prime} \mathrm{E}$ long. in the central region of Saudi Arabia occupying a large area of Najd plateau with an average altitude of $600 \mathrm{~m}$ above sea level. Riyadh is characterized by several mountains (e.g. the Tuwaiq Mountains) and sand dunes. Similar to Qassim, Riyadh is divided into two geological sectors; the western part is the Arabian Shield sector and the eastern is the sedimentary sector (Fig. 1).

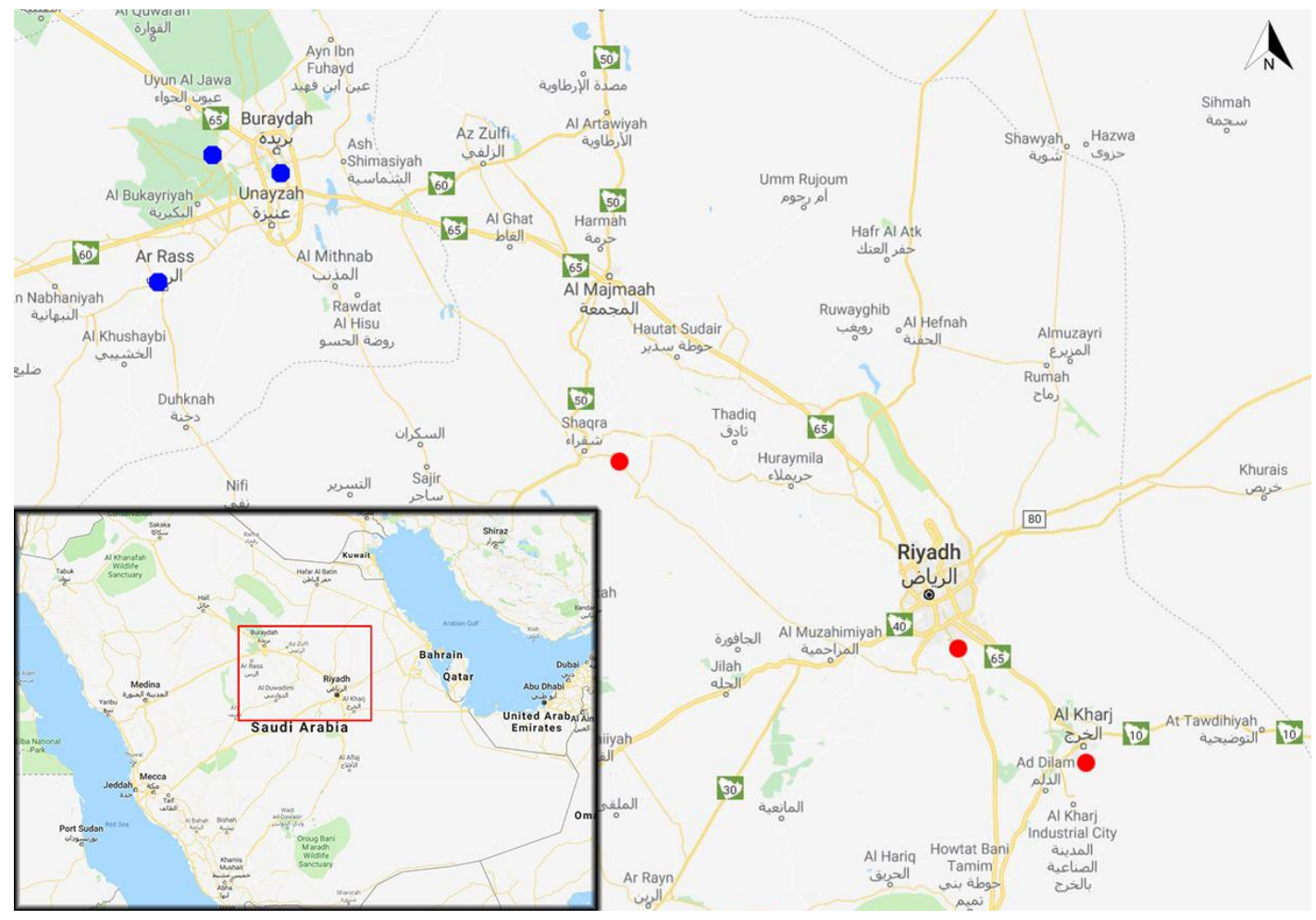

Figure 1. A map showing the different studied sites

The study area is characterized by high temperatures especially from June to August when the temperature can exceed $45^{\circ} \mathrm{C}$. The general climate in the study area is hot summer and mild to cold winter. The rainfall is very low with an average of less than $200 \mathrm{~mm} / \mathrm{month}$, and most of the rain falls during spring with almost no rain in the summer. The wind is usually laden with dust from upwind desert areas. Table 1 summarizes the climate characteristics of the two studied areas; Riyadh and Qassim. 
Table 1. Average of climate records for 10 years (2005 - 2014) in Riyadh and Qassim areas (Source: Saudi General Authority of Meteorology and Environmental Protection)

\begin{tabular}{c|cc|cc}
\hline Climate variable & \multicolumn{2}{|c|}{ Riyadh } & \multicolumn{2}{c}{ Qassim } \\
& Range & Mean & Range & Mean \\
\hline Max air temperature $\left({ }^{\circ} \mathrm{C}\right)$ & $20.95-43.93$ & 32.44 & $20.43-44.72$ & 32.58 \\
Min air temperature $\left({ }^{\circ} \mathrm{C}\right)$ & $7.48-27.66$ & 17.57 & $6.74-27.33$ & 17.00 \\
Rainfall $(\mathrm{mm} / \mathrm{mon}$ (h) & $0.00-320.91$ & 160.46 & $0.00-320.00$ & 160.00 \\
Relative humidity $(\%)$ & $8.30-94.30$ & 51.30 & $4.20-99.80$ & 52.00 \\
Wind speed $(\mathrm{km} / \mathrm{h})$ & $4.10-7.10$ & 5.6 & $4.90-7.40$ & 6.15 \\
\hline
\end{tabular}

\section{Sample stands}

In the present study, 63 different stands were selected to represent the two main studied habitats (sabkhas and sewage canals) that exist in different wetlands in the central region of Saudi Arabia. GPS coordinates for all the studied stands were recorded (Appendix 1) and in every stand, an area of $50 \mathrm{~m} \times 50 \mathrm{~m}$ was sampled. Sampling was carried out during the spring season 2016 in order to ascertain the maximum presence of the different plant species. Plant samples collected from each stand were identified according to Collenette (1999) and Chaudhary (2001) and presented at the herbarium of King Saud University, Riyadh, Saudi Arabia. Plants were classified into annual herbs, annual grasses, perennial herbs, perennial grasses and shrubs (Appendix 2). The pattern of geographical distribution (chorotype) of each species were studied following Chaudhary (2001). The total and mean cover and presence of each species were calculated for each stand following the method described by Kent (2012).

\section{Soil analysis}

Three soil samples were collected from each stand at a depth of $50 \mathrm{~cm}$ and mixed together to form a composite sample. Soil physical and chemical characteristics were assessed. The hydrometer method was used to determine the soil texture (Day, 1965). The "Loss on Ignition" method (combustion at $550^{\circ} \mathrm{C}$ ) was used to calculate the total organic matter present in the soil samples. Soil $\mathrm{pH}$ and electrical conductivity (EC) was calculated in soil suspension 1: $5 \mathrm{w}$ : v. Nitrogen content in soil samples was determined using the micro Kjeldahl method (AOAC, 1990). Phosphorus content was determined following the method of APHA (2005). Concentrations of various nutrients $(\mathrm{Ca}, \mathrm{K}, \mathrm{Mg}$, $\mathrm{Fe}, \mathrm{Na}$ ) were measured following the methods described by Allen (1989).

\section{Water analysis}

One water sample from each stand was collected (where applicable) and chemical analyses were performed. Samples were collected at a depth of $1 \mathrm{~m}$ above surface that is around the middle of each water body. Water $\mathrm{pH}$ and $\mathrm{EC}$ were examined according to Allen (1989). Phosphorus content was determined following the method of APHA (2005). In addition, levels of $\mathrm{Ca}, \mathrm{K}, \mathrm{Mg}, \mathrm{Fe}$ and $\mathrm{Na}$ in the water samples were investigated (Allen, 1989).

\section{Statistical analysis}

Canonical correspondence analysis (CCA) and detrended correspondence analysis (DCA) using DECORANA software (Hill, 1979a) and multivariate analysis using 
TWINSPAN software (Hill, 1979b) were performed to calculate the estimates of cover for 109 plant species collected from the 63 stands. Species richness ( $\alpha$-diversity) was defined as the average number of species present in each individual stand. Gamma diversity ( $\gamma$-diversity) was determined based on the total number of species for each stand. The relative cover $\left(p_{i}\right)$ of each stand was used to calculate the relative evenness using the Shannon-Wiener index $\widehat{H}=-\sum_{i=1}^{s} p_{i} \log p_{i}$ and the relative dominance concentration using the Simpson index $C=\sum_{i=1}^{s} p_{i}^{2}$ where $s$ is the total number of species collected (Pielou, 1975; Magurran, 1988).

\section{Results}

The total number of plants collected from the different wetlands studied in the Riyadh and Qassim areas was 109 plant species belonging to 83 different genera and 34 different plant families, with a species richness factor of 1.31 (109 species / 83 genera). The most abundant plant families were Chenopodiaceae with 18 different plant species (16.5\%), Poaceae represented by 16 different plant species (14.7\%), Asteraceae with 10 different plant species (9.2\%) and Fabaceae with 7 different plant species (6.4\%). The least abundant families were Aizoaceae, Amaranthaceae, Apocynaceae, Asphodelaceae, Cistaceae, Cucurbitaceae, Ephedraceae, Frankeniaceae, Juncaceae, Lamiaceae, Malvaceae, Molluginaceae, Neuradaceae, Orobanchaceae, Portulacaceae and Ruppiaceae, with each family being represented by only one plant species (Fig. $2 a$, bar chart). Fig. $2 b$ (pie chart) shows that the predominant life forms were annual herbs with 40 different plant species $(36.7 \%)$ and perennial herbs with 34 different plant species $(31.2 \%)$. The total number of different annual species was $45(41.3 \%)$, while the perennial species were represented by 64 different species $(58.7 \%)$. In terms of the global geographical distribution of the plants collected, the most represented regions were the Saharo-Arabian region with 39 (35.10\%) different plant species followed by the bi-regional Saharo Arabian-Somalia Masai with 10 (9.2) different plant species and the Tropical and Saharo Arabian-Irano Turanian regions with 8 (7.3\%) different plant species for each. Generally, the most abundant species were those typically found in a single region (52 species, 46.9\%) and the bi-regional species (30 species, 28.4\%) while the multi-regional and cosmopolitan species were the least abundant with 12 species $(11.0 \%)$ and 1 species $(0.9 \%)$, respectively. The most abundant plant species in all the habitats studied were Phragmites australis (with a relative presence ' $\mathrm{P}$ ' $=41.3 \%$, a relative coverage ' $\mathrm{C}$ ' $=15.4 \%)$, Tamarix nilotica $(\mathrm{P}=39.4 \%, \mathrm{C}=5.71 \%)$, Salosola imbricate $(\mathrm{P}=34.9 \%, \mathrm{C}=1.32 \%)$, Zygophyllum propinquum ssp. migahidii $(\mathrm{P}=$ $25.4 \%, \mathrm{C}=16.0 \%)$ and Tamarix aucheriana $(\mathrm{P}=25.4 \%, \mathrm{C}=16.0 \%)$. In contrast, the rarest plants $(\leq 1)$ in the habitats studied included (for example) Aizoon canariense, Chenopodium album, Plantago amplexicaulis and Salvia spinosa.

In the present study, two forms of wetlands in Saudi Arabia were studied, namely sabkhas (natural) and sewage canals (industrial). Seventy-nine different plant species belonging to 69 genera and 28 families were found in sabkhal habitats. Chenopodiaceae, Poaceae and Asteraceae were the most highly represented plant families with 14, 14 and 7 plant species, respectively. Most of the plant species in sabkhas were annual herbs (34 species, $43 \%)$ and perennial herbs (20 species, 25.3\%). The most abundant plant species were Tamarix aucheriana $(\mathrm{P}=39.47 \%, \mathrm{C}=13.16 \%)$ and Zygophyllum propinquumm ssp.migahidii $(\mathrm{P}=34.21 \%, \mathrm{C}=4.03 \%)$, while the rarest plant species were Chenopodium album and Salvia spinosa. In contrast, in sewage canal habitats, 58 different plant 
species belonging to 50 genera and 26 families were found. The most abundant families there were members of the Poaceae (9 species, 15.5\%) and Chenopodiaceae ( 8 species, $13.8 \%)$. Perennial herbs twenty different species $(34.5 \%)$ were the most represented group followed by annual herbs with 16 species (27.6\%). Phragmites australis was the most abundant plant species $(\mathrm{P}=57.69 \%, \mathrm{C}=24.04 \%)$ followed by Tamarix nilotica $(\mathrm{P}=50.00 \%, \mathrm{C}=8.85 \%)$, Calotropis procera $(\mathrm{P}=38.46 \%, \mathrm{C}=8.31 \%)$ and Pulicaria undulata $(\mathrm{P}=38.46 \%, \mathrm{C}=6.92 \%)$. In contrast, Aeluropus lagopoides and Amaranthus viridis were the rarest plants (Appendix 1).

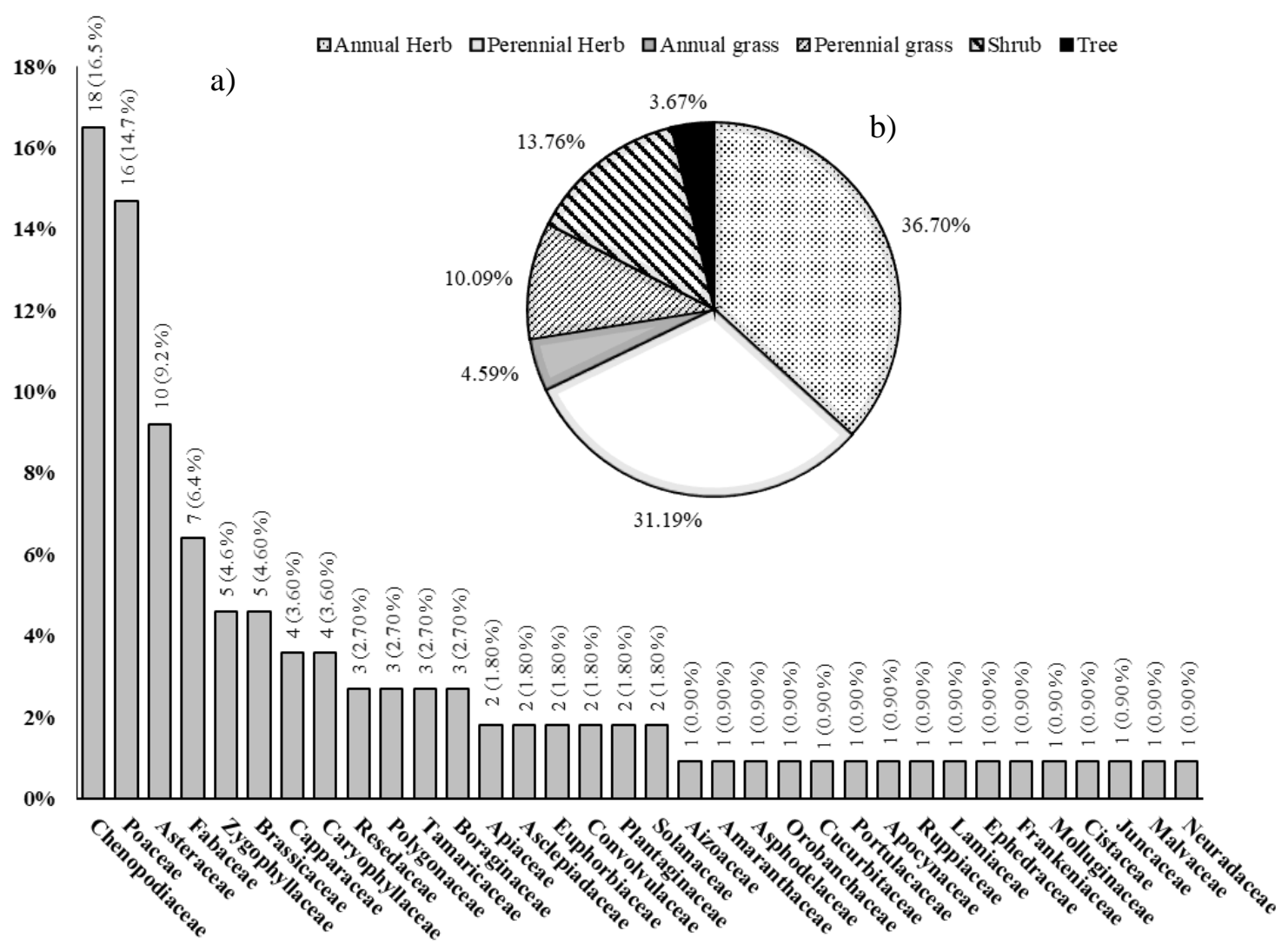

Figure 2. (a) Number and percentages of different represented families (bar chart) and (b) lifeforms (pie chart) in the studied stands.

Cover estimates for 109 plants collected from 63 different stands using TWINSPAN software generated 6 different vegetation groups at the third level of classification (Fig. $3 a$, Table 2). Of these groups, only two groups only occupied sabkhas habitats; a) that characterized by Tamarix aucheriana - Phragmites australis and b) that characterized by Centropodium forsskalii - Emex spinosa. One group occupied sewage canals only (Calotropis procera - Citrullus colocynthis), two groups mainly occupied sabkhas; a) Suaeda vermiculata - Seidletzia rosmarinus - Zygophyllum propinquum ssp. Migahidii and b) Haloxylon salicornicum - Suaeda aegyptiaca. One group mainly occupied sewage canals (Tamarix nilotica - Salsola imbricata). Further analysis of the same data set using DECORANA software showed a reasonable segregation between the groups that had been generated (Fig. 3b). 
Table 2. Characteristics of different vegetation groups produced by TWINSPAN

\begin{tabular}{|c|c|c|c|c|c|c|c|c|c|c|c|}
\hline \multirow{2}{*}{ VG } & \multirow{2}{*}{ Stands } & \multirow{2}{*}{ Stands $(\%)$} & \multirow{2}{*}{ Species } & \multicolumn{2}{|c|}{ Habitats } & \multirow{2}{*}{ First dominant species } & \multirow{2}{*}{ P\% } & \multirow{2}{*}{$\mathrm{C} \%$} & \multirow{2}{*}{ Second dominant species } & \multirow{2}{*}{$\mathbf{P \%}$} & \multirow{2}{*}{$\mathrm{C} \%$} \\
\hline & & & & Sabkhas & Sewage & & & & & & \\
\hline 1 & 7 & 11.00 & 35 & 71.4 & 28.6 & Haloxylon salicornicum & 57 & 18.86 & Suaeda aegyptiaca & 43 & 6.43 \\
\hline 2 & 10 & 15.87 & 31 & 80 & 20 & Suaeda vermiculata & 43 & 10.9 & $\begin{array}{c}\text { Seidletzia Rosmarinus } \\
\text { Zygophyllum propinquum } \\
\text { ssp. migahidii. }\end{array}$ & $\begin{array}{l}50 \\
50\end{array}$ & $\begin{array}{l}10 \\
8.2\end{array}$ \\
\hline 3 & 16 & 25.40 & 70 & 100 & 0 & Tamarix aucheriana & 56 & 25 & Phragmites australis & 56 & 16.31 \\
\hline 4 & 19 & 30.16 & 59 & 36.8 & 63.2 & Tamarix nilotica & 63 & 16.84 & Salsola imbricata & 47 & 3.58 \\
\hline 5 & 9 & 14.29 & 41 & 0 & 100 & Calotropis procera & 44 & 15.78 & Citrullus colocynthis & 33 & 2.0 \\
\hline 6 & 2 & 3.17 & 6 & 100 & 0 & Centropodium forsskalii & 50 & 3.89 & Emex spinosa. & 50 & 1.0 \\
\hline
\end{tabular}

P: presence of species, $\mathrm{C}$ : relative cover of species 
(a)

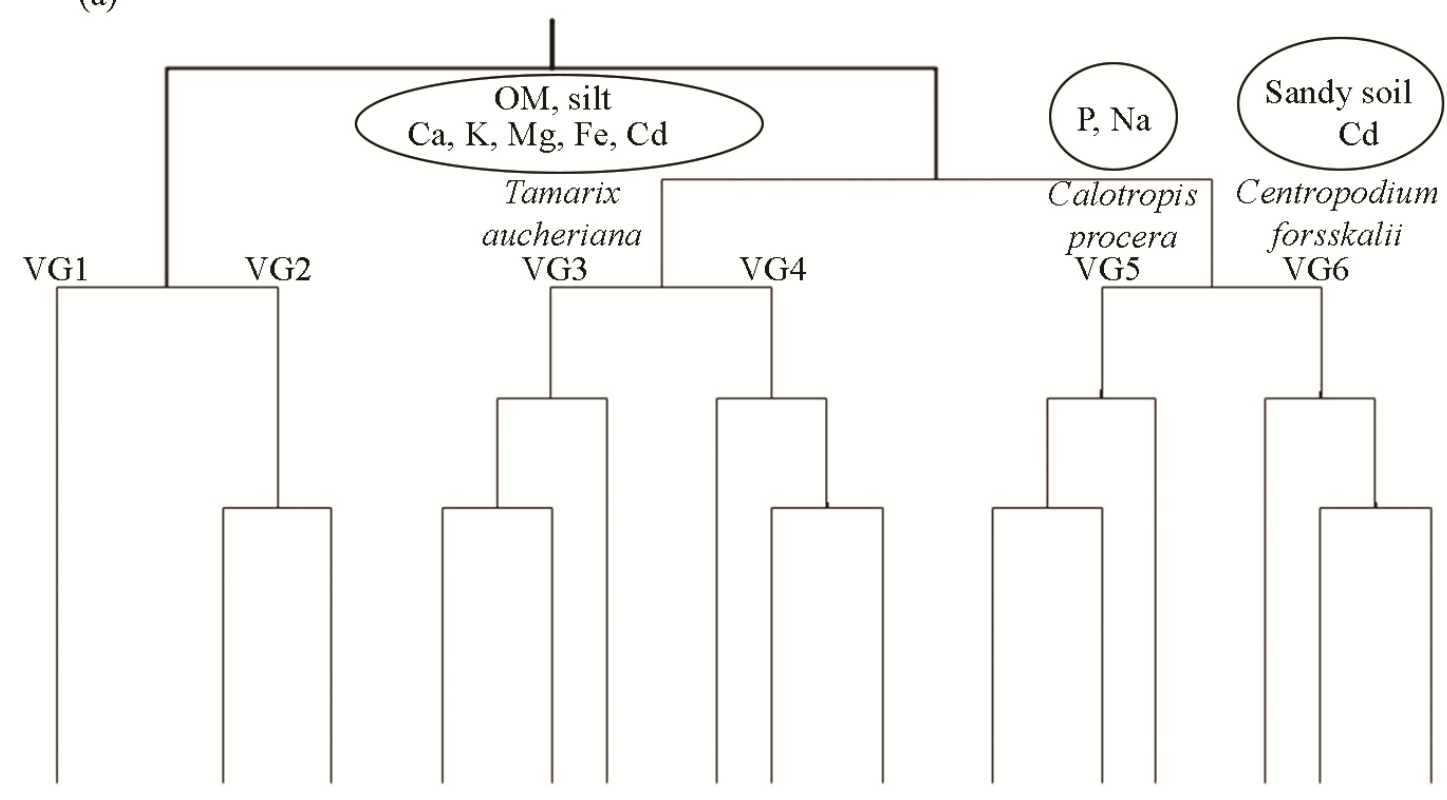

(b)

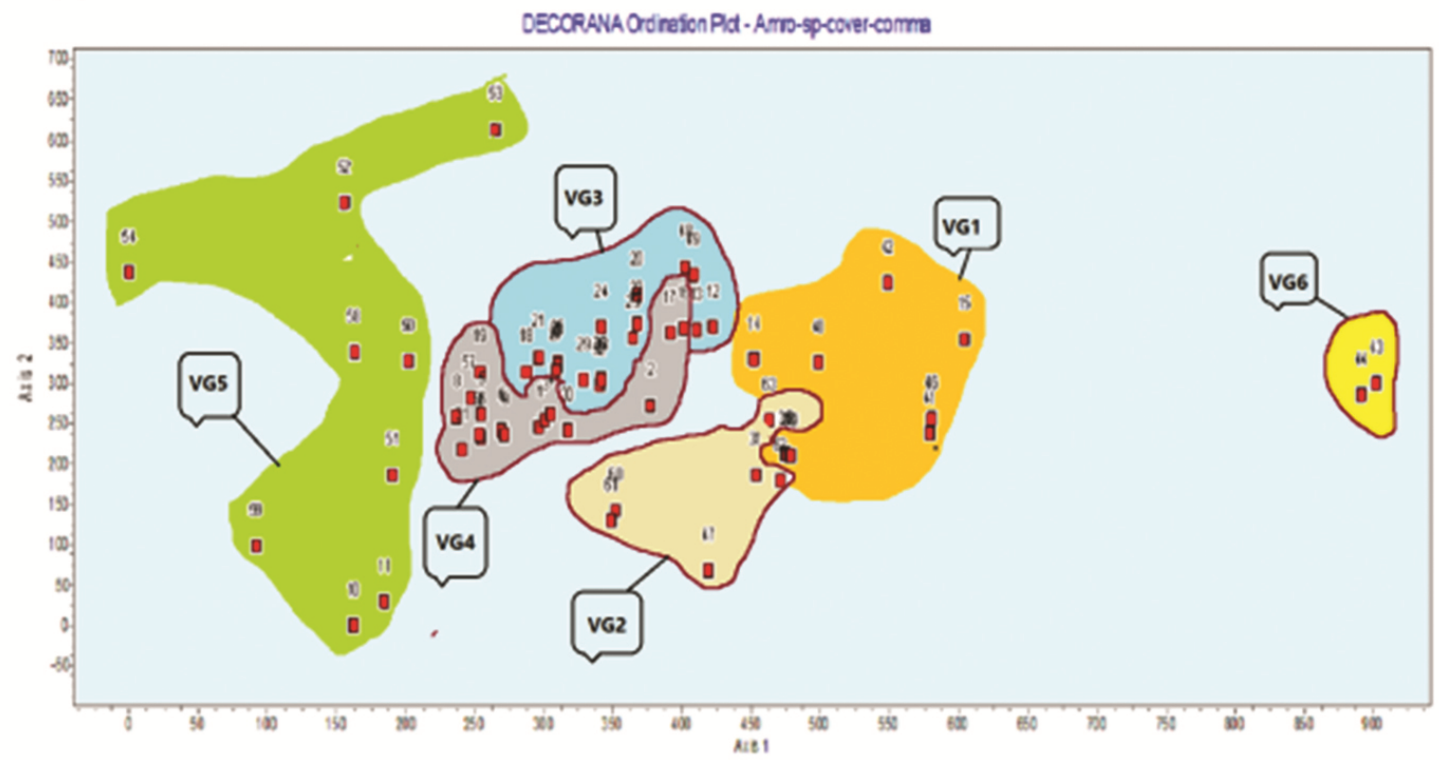

Figure 3. (a) Dendogram showing the relationship between 6 different vegetation groups generated by TWINSPAN and (b) Segregation of different vegetation groups after applying DECORANA analysis.

CCA analysis showed that different environmental factors related to soil affect the species distribution on the two axes. There was a positive correlation between the Simpson index value and the first axis and a negative correlation between the same axis and $\mathrm{EC}, \mathrm{Ca}, \mathrm{Mg}, \mathrm{Cr}$ and $\mathrm{Cd}$. Meantime, the second axis correlated negatively with silt percentage in soil, organic matter, $\mathrm{Ca}, \mathrm{K}, \mathrm{Mg}$, and $\mathrm{Cd}$ (Fig. 4a). Plant species recognized as psammophytic (associated with sandy soils) occupied the positive upper left and right sides of the CCA plot (Fig. 4b) and showed a positive correlation with the 
Shannon-Wiener index, evenness, species richness, sand percentage in soil, $\mathrm{Zn}$ and Na. Psammophytic plants included, for example, Bassia eriophora, Pennisetum divisum, Cynodon dactylon and Asphoedelus tenuifolius. Shrubs such as Calotropis procera, Tamarix aucheriana and Heliotropium digynum were found on the lower side of the first axis and showed a strong correlation with the Simpson index and P content. Halophytes mainly occupied the negative lower side of the first axis and showed strong correlation with increasing $\mathrm{pH}, \mathrm{EC}, \mathrm{Cr}, \mathrm{Pb}, \mathrm{Mg}$ and organic matter. This group of plants included, for example, Aeluropus lagopoides, Salicornia europaea and Juncus rigidus.

(a)
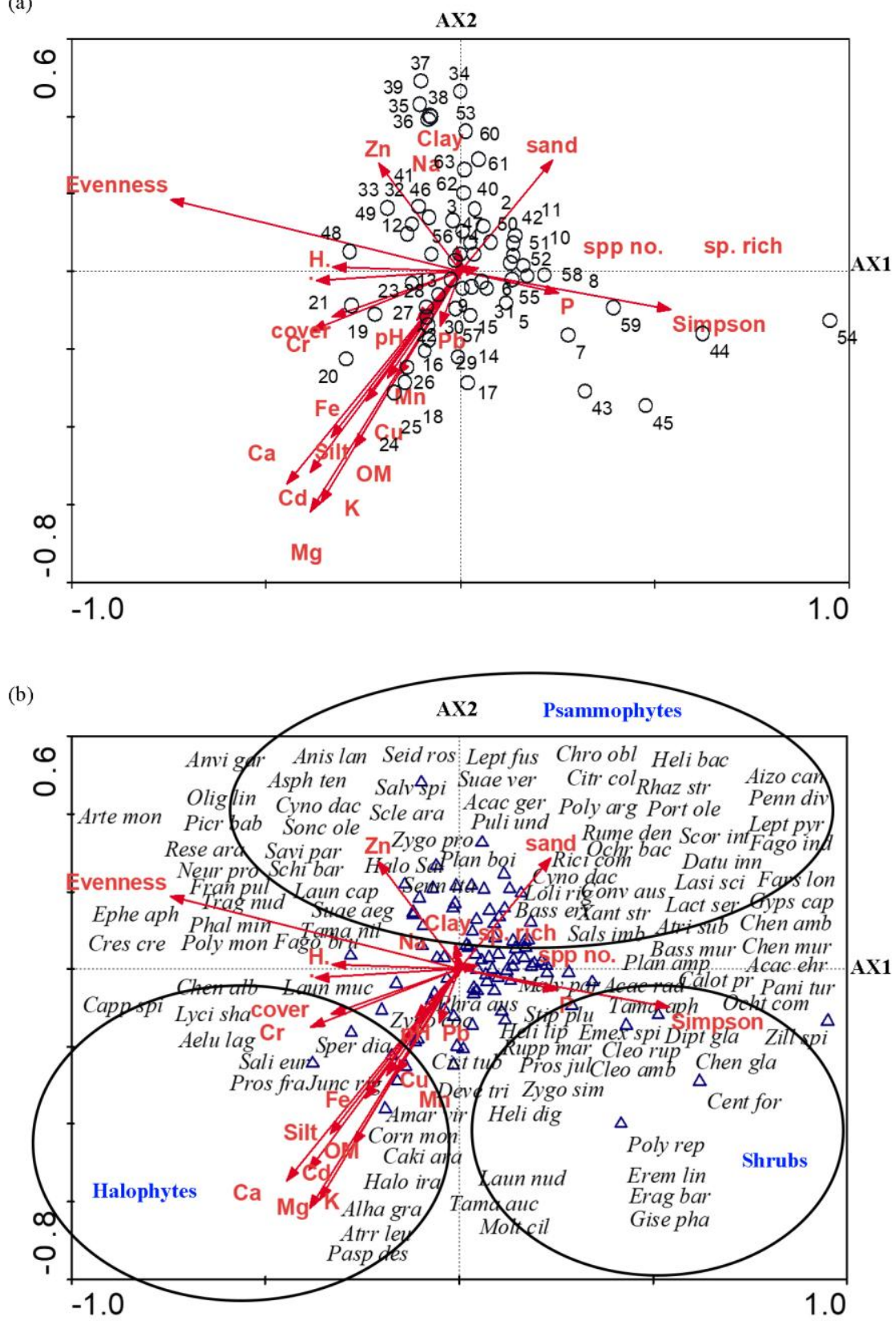

Figure 4. (a) The CCA plot shows the relationships between the stands studied and the soil characteristics and biological indices (the Simpson index and measures of evenness). (b) The same plot showing the abundant species represented by the first four letters of genus and first three letters of species. 


\section{Discussion}

Wetlands are considered a very significant habitat for diverse group of animals, plants and even microbes. In addition to their important role in the water cycle, and in removing excess nutrients and other contaminants from polluted water, they are one of the most biodiverse sites around the world. Wetlands contribute significantly in keeping the ecological balance between different plant species. In Saudi Arabia, wetlands are the richest habitats from the point of view of plant diversity because of the availability of moisture, in contrast to the many dry places around the kingdom. In this study of the vegetation of 63 different sites, it was found that perennial plants were the most abundant life forms. Our earlier (unpublished) studied on wetlands in Saudi Arabia have also shown that perennial plants are more abundant than annual plants in valley habitats in the Riyadh area. In contrast, we found that annual plants were more abundant in Sabkha habitat in the Qassim area (unpublished data). Levels of species richness (1.31) in this study indicated the high plant diversity at the region. Members of the Chenopodiaceae family were the most abundant family in the stands studied. This may be due to the high tolerance of drought and salinity typical of the members of this family. Stebbins (1974) pointed out that the Chenopodiaceae plants were typically able to grow in saline sandy soils such as sabkhas. It could, also, be due to the fact that members of the Chenopodiaceae disperse readily due to their lightweight seeds (ElSheikh, 2013). In the present study, where the Chenopodiaceae were most abundant, they were followed by Poaceae and Asteraceae. In contrast, at the level of Saudi Arabia as a whole, Chaudhary (2001) found that the most abundant families were first, the Poaceae followed by the Chenopodiaceae and the Zygophyllaceae.

In the present study, perennial plants were more represented than annuals. Wetlands habitats such as sabkhas and sewage treatment areas are very different from the dryland areas, in that they provide the moisture required by plants, and do so year-round. In addition, soils in wetlands have higher concentrations of various nutrients that promote the growth of various perennial species. The dominant plants in wetlands are trees as they can tolerate drought stress for longer periods, and they can draw water from surface and deep soil via their extensive root systems (Al-Rowaily et al., 2012). Chorotype analysis showed that mono-regional plants were the most abundant and were represented by the Saharo Arabian, Tropical and Irano-Turanian groups, respectively. The study stands are located, mainly, in the Arab Sahara Region located between the Tropical and Irano-Turanian regions (Alatar et al., 2012). The central region of Saudi Arabia is a part of the Arab Sahara Region and their plants are mainly mono-regional belonging to the Saharo Arabian group (Al-Nafie, 2008). The presence of plants normally associated with Saharo Arabian-Somalia Masai, Saharo Arabian-Irano Turanian and Mediterranean-Irano Turanian floras indicate that the central region of Saudi Arabia is a transitional area with some of the characteristics of surrounding regions. This supports earlier vegetation studies of the central region (Alatar et al., 2012; Alatar et al., 2015) and studies of Kuwait (El-Sheikh et al., 2012).

TWINSPAN analysis showed that there were 6 different vegetation groups in the study sites. Shaltout et al. (1997) studied the vegetation of coastal lowland of eastern Saudi Arabia. In their analysis, they found 12 different vegetation groups include Tamarix aucheriana and Phragmites australis communities. In addition, Phragmites australis was found in the Hail region in northern Saudi Arabia (El-Ghanim et al., 2010). In the present study, it was found that salinity, soil texture and nutrient levels were the main environmental factors affecting the distribution of plants in each stand. 
Our results are supported by other studies of similar habitats (Alatar et al., 2012; ElSheikh et al., 2012). The Shannon index showed a positive correlation with sand content in soil because soils with more sandy texture provide soil aeration in wetlands such as sabkhas and sewage canals. Furthermore, percentage of cover was positively correlated with organic matter content and potassium levels. Shrubs and trees benefit from the presence of high organic matter which as it decomposes provides nutrients for growth, allowing development of significant biomass (Alatar et al., 2015). Other macronutrients especially $\mathrm{K}, \mathrm{Mg}$ and $\mathrm{Ca}$ also play a critical role in maintaining plant osmotic pressure in a saline environment, adjusting the $\mathrm{pH}$ of the plant cell, protecting cells from toxicity and serving as co-factors for several enzymes (Shiel, 2001).

Psammophytic plants were the most abundant lifeform in the stands studied followed by halophytes and shrubs. This pattern reflects characteristics of the whole flora of Saudi Arabia (Chaudhary, 2001). Psammophytic plants were correlated with Shannon index, species evenness, species richness and number of species in each stand. Increased plant cover may promote higher chlorophyll content in plants as a result of competition and shading. Abou-Sitta and Al-Taisan (1995) found that desert plant growing in shade had higher chlorophyll content than plants growing in sunny areas. Higher chlorophyll content enhancing plant's ability to photosynthesize and produce the carbohydrates essential for growth. There was a clear correlation between halophytes and the EC of the soil. Clearly, we could expect halophytic plants to be the most abundant group of plants under high salinity conditions (Alatar et al., 2012; El-Sheikh et al., 2012). In the present study, the third and sixth vegetation groups which dominated by Tamarix aucheriana and Centropodium forsskalii, respectively, were found only in sabkha habitats. This could be attributed to the high salinity levels in these habitats. Halophytes are, also, able to hyperaccumulate some of the heavy metals including $\mathrm{Cr}, \mathrm{Pb}, \mathrm{Fe}, \mathrm{Mn}$, $\mathrm{Cu}$ and $\mathrm{Cd}$. Heavy metals hyperaccumulators can remediate contaminated soil by sorting such metals in inert forms in their vacuoles using a mechanism similar to the one that halophytes use to cope with salinity (Van Oosten and Maggio, 2015). In the present investigation, the fifth vegetation group dominated by Calotropis procera was found only in sewage canals habitats. These habitats were characterized by high levels of heavy metals. This could be an explanation for the high presence of Calotropis procera in these habitats because its high ability to accumulate heavy metals (Galal et al., 2016).

The vegetation of the sabkhas and sewage canals in this study fell into 6 different vegetation groups. The third vegetation group, dominated by Tamarix aucheriana and Phragmites australis, showed high values of percentage of cover and a high Shannon index associated with high soil organic matter, silt percentage in the soil and concentrations of $\mathrm{Ca}, \mathrm{K}, \mathrm{Mg}, \mathrm{Fe}$ and $\mathrm{Cd}$. In contrast, the fifth vegetation group, dominated by Calotropis procera and Citrullus colocynthis, was associated with high soil concentrations of $\mathrm{Na}$ and $\mathrm{P}$. This could be due to the role of $\mathrm{Na}$ in maintaining $\mathrm{pH}$ and ionic balance in plant cells and tissues, and the essential role of $\mathrm{P}$ as a macronutrient required for the biosynthesis of amino acids and nuclear proteins (Shiel, 2001). The sixth vegetation group, dominated by Centropodium forsskalii and Emex spinosa, was associated with high values of species richness and a high Simpson index. This vegetation group was mainly found in sand habitats with good soil conditions. Sandy soils are particularly suitable for growth of various annual herbs and grasses. The distribution of such plants is related to salinity. 


\section{REFERENCES}

[1] Abou-Sitta, Y. M., Al-Taisan, W. A. (1995): Variations in mineral ion composition of some succulent halophytes in the Eastern coastal province of Saudi Arabia. - Desert Institute Bulletin, Egypt 45(1): 99-110.

[2] Al-Nafie, A. H. (2008): Phytogeography of Saudi Arabia. - Saudi J. Biol. Sci. 15: 159176.

[3] Al-Obaid, S., Samraoui, B., Thomas, J., El-Serehy, H. A., Alfarhan, A. H., Schneider, W., O'Connell, M. (2017): An overview of wetlands of Saudi Arabia: Values, threats, and perspectives. - Ambio 46(1): 98-108.

[4] Al-Rowaily, S. L., El-Bana, M. I., Al-Dujain, F. A. R. (2012): Changes in vegetation composition and diversity in relation to morphometry, soil and grazing on a hyper-arid watershed in the central Saudi Arabia. - CATENA 97(Supplement C): 41-49.

[5] Alatar, A. A., El-Sheikh, M. A., Thomas, J. (2012): Vegetation analysis of Wadi AlJufair, a hyper-arid region in Najd, Saudi Arabia. - Saudi J. Biol. Sci. 19(1): 43-54.

[6] Alatar, A. A., El-Sheikh, M. A. R., Thomas, J., Hegazy, A. K., El Adawy, H. A. (2015): Vegetation, Floristic Diversity, and Size-Classes of Acacia gerrardii in an Arid Wadi Ecosystem. - Arid Land Res. Manage. 29(3): 335-359.

[7] Allen, S. E. (1989): Chemical analysis of ecological materials. (2nd ed.) - Oxford: Blackwell Scientific.

[8] AOAC (1990). Official methods of analysis of AOAC International.

[9] APHA (2005). Standard Methods for the Examination of Water and Wastewater. (21st ed.) - Washington, DC: American Public Health Association.

[10] Brinson, M. M. (2011): Classification of Wetlands. - In: LePage, B.A. (ed.) Wetlands: Integrating Multidisciplinary Concepts. Dordrecht: Springer Netherlands: 95-113.

[11] Chaudhary, S. A. (2001): Flora of the Kingdom of Saudi Arabia. Vol. 2. - Riyadh: Ministry of Agriculture and Water.

[12] Collenette, S. (1999): Wildflowers of Saudi Arabia. - Riyadh: National Commission for Wildlife Conservation and Development (NCWCD).

[13] Day, P. R. (1965): Particle Fractionation and Particle-Size Analysis. - In: Black, C.A. (ed.) Methods of Soil Analysis. Madison: American Society of Agronomy Inc.: 545-567.

[14] El-Ghanim, W. M., Hassan, L. M., Galal, T. M., Badr, A. (2010): Floristic composition and vegetation analysis in Hail region north of central Saudi Arabia. - Saudi J. Biol. Sci. 17(2): 119-128.

[15] El-Sheikh, M. A. (2013): Population structure of woody plants in the arid cloud forests of Dhofar, southern Oman. - Acta Bot. Croat. 72(1): 97-111.

[16] El-Sheikh, M. A., Abbadi, G. A., Alatar, A. A. (2012): Phytosociological behavior \& mineral allocation in Panicum turgidum Forssk. along the coast of the Arabian Gulf, Kuwait. - Feddes Repert. 3: 177-192.

[17] Flinn, K. M., Lechowicz, M. J., Waterway, M. J. (2008): Plant species diversity and composition of wetlands within an upland forest. - Am. J. Bot. 95(10): 1216-1224.

[18] Galal, T. M., Farahat, E. A., El-Midany, M. M., Hassan, L. M. (2016): Nutrients and heavy metals accumulation by the giant milkweed Calotropis procera (Aiton) W.T. Aiton in urbanized areas, Egypt. - Rendiconti Lincei. 27(2): 241-250.

[19] Hill, M. O. (1979a): DECORANA: A FORTRAN Program for Detrended Correspondence Analysis and Reciprocal Averaging. - NY: Section of Ecology and Systematics, Cornell University.

[20] Hill, M. O. (1979b): TWINSPAN: A FORTRAN Program for Arranging Multivariate Data in an Ordered Two-way Table by Classification of the Individuals and Attributes. NY: Section of Ecology and Systematics, Cornell University.

[21] Kent, M. (2012): Vegetation Description and Data Analysis: A Practical Approach. (2nd ed.) - Chichester: John Wiley \& Sons. 
[22] LePage, B. A. (2011): Wetlands: A Multidisciplinary Perspective. - In: LePage, B.A. (ed.) Wetlands: Integrating Multidisciplinary Concepts. Dordrecht: Springer Netherlands: 3-25.

[23] Magurran, A. E. (1988): Diversity indices and species abundance models. - In: Magurran, A. E. (ed.) Ecological Diversity and Its Measurement. Dordrecht: Springer Netherlands: 7-45.

[24] Pielou, E. C. (1975): Ecological diversity. - NY: Wiley.

[25] Shaltout, K. H., El-Halawany, E. F., El-Garawany, M. M. (1997): Coastal lowland vegetation of eastern Saudi Arabia. - Biodivers. Conserv. 6(7): 1027-1040.

[26] Shiel, R. S. (2001): Nutrient Elements in Grassland: Soil-Plant-Animal Relationships. Eur. J. Soil Sci. 52(3): 523-524.

[27] Stebbins, G. L. (1974): Flowering plants, Evolution Above the Species Level. Cambridge: M. A. the Belknap Press of Harvard University.

[28] Van Oosten, M. J., Maggio, A. (2015): Functional biology of halophytes in the phytoremediation of heavy metal contaminated soils. - Environ. Exp. Bot. 111(Supplement C): 135-146.

\section{APPENDIX}

Appendix 1. GPS coordinates of the studied stands in Riyadh and Qassim regions

\begin{tabular}{|c|c|c|c|c|c|c|c|}
\hline $\begin{array}{c}\text { Stand } \\
\text { No. }\end{array}$ & Habitat & Coordinates & $\begin{array}{c}\text { Altitude } \\
(\mathbf{m})\end{array}$ & $\begin{array}{l}\text { Stand } \\
\text { No. }\end{array}$ & Habitat & Coordinates & $\begin{array}{c}\text { Altitude } \\
(\mathbf{m})\end{array}$ \\
\hline 1 & $\begin{array}{l}\text { Sewage, } \\
\text { Riyadh }\end{array}$ & $\begin{array}{l}\text { N } 24^{\circ} 06^{\prime} 05.5^{\prime \prime} \\
\text { E } 47^{\circ} 23^{\prime} 21.4^{\prime \prime}\end{array}$ & 421 & 33 & $\begin{array}{l}\text { Sabkha, } \\
\text { Qassim }\end{array}$ & $\begin{array}{l}\text { N } 26^{\circ} 01^{\prime} 20.57^{\prime \prime} \\
\text { E } 44^{\circ} 10^{\prime} 33.07^{\prime \prime}\end{array}$ & 608 \\
\hline 2 & $\begin{array}{l}\text { Sewage, } \\
\text { Riyadh }\end{array}$ & $\begin{array}{l}\text { N } 24^{\circ} 06^{\prime} 01.9^{\prime \prime} \\
\text { E } 47^{\circ} 23^{\prime} 14.9^{\prime \prime}\end{array}$ & 420 & 34 & $\begin{array}{l}\text { Sabkha, } \\
\text { Qassim }\end{array}$ & $\begin{array}{l}\mathrm{N} 26^{\circ} 23^{\prime} 09.1^{\prime \prime} \\
\mathrm{E} 43^{\circ} 48^{\prime} 14.5^{\prime \prime}\end{array}$ & 629 \\
\hline 3 & $\begin{array}{l}\text { Sewage, } \\
\text { Riyadh }\end{array}$ & $\begin{array}{l}\text { N } 24^{\circ} 05^{\prime} 58.7^{\prime \prime} \\
\text { E } 47^{\circ} 23^{\prime} 08.5^{\prime \prime}\end{array}$ & 420 & 35 & $\begin{array}{l}\text { Sabkha, } \\
\text { Qassim }\end{array}$ & $\begin{array}{l}\text { N } 26^{\circ} 23^{\prime} 23.3^{\prime \prime} \\
\text { E } 43^{\circ} 47^{\prime} 42.5^{\prime \prime}\end{array}$ & 629 \\
\hline 4 & $\begin{array}{l}\text { Sewage, } \\
\text { Riyadh }\end{array}$ & $\begin{array}{l}\text { N } 24^{\circ} 06^{\prime} 07.9^{\prime \prime} \\
\text { E } 47^{\circ} 23^{\prime} 32.3^{\prime \prime}\end{array}$ & 421 & 36 & $\begin{array}{l}\text { Sabkha, } \\
\text { Qassim }\end{array}$ & $\begin{array}{l}\text { N } 26^{\circ} 23^{\prime} 39.13^{\prime \prime} \\
\text { E } 43^{\circ} 47^{\prime} 21.48^{\prime \prime}\end{array}$ & 629 \\
\hline 5 & $\begin{array}{l}\text { Sewage, } \\
\text { Riyadh }\end{array}$ & $\begin{array}{l}\text { N } 24^{\circ} 06^{\prime} 15.7^{\prime \prime} \\
\text { E } 47^{\circ} 23^{\prime} 22.4^{\prime \prime}\end{array}$ & 421 & 37 & $\begin{array}{l}\text { Sabkha, } \\
\text { Qassim }\end{array}$ & $\begin{array}{l}\text { N } 26^{\circ} 23^{\prime} 44.8^{\prime \prime} \\
\text { E } 43^{\circ} 47^{\prime} 54.3^{\prime \prime}\end{array}$ & 634 \\
\hline 6 & $\begin{array}{l}\text { Sewage, } \\
\text { Riyadh }\end{array}$ & $\begin{array}{l}\text { N } 24^{\circ} 06^{\prime} 38.7^{\prime \prime} \\
\text { E } 47^{\circ} 23^{\prime} 34.4^{\prime \prime}\end{array}$ & 420 & 38 & $\begin{array}{l}\text { Sabkha, } \\
\text { Qassim }\end{array}$ & $\begin{array}{l}\text { N } 26^{\circ} 23^{\prime} 48.5^{\prime \prime} \\
\text { E } 43^{\circ} 48^{\prime} 39.7^{\prime \prime}\end{array}$ & 635 \\
\hline 7 & $\begin{array}{l}\text { Sewage, } \\
\text { Riyadh }\end{array}$ & $\begin{array}{l}\text { N } 24^{\circ} 05^{\prime} 50.9^{\prime \prime} \\
\text { E } 47^{\circ} 22^{\prime} 42.7^{\prime \prime}\end{array}$ & 417 & 39 & $\begin{array}{l}\text { Sabkha, } \\
\text { Qassim }\end{array}$ & $\begin{array}{l}\text { N } 26^{\circ} 23^{\prime} 26.26^{\prime \prime} \\
\text { E } 43^{\circ} 48^{\prime} 58.21^{\prime \prime}\end{array}$ & 625 \\
\hline 8 & $\begin{array}{l}\text { Sewage, } \\
\text { Riyadh }\end{array}$ & $\begin{array}{l}\text { N } 24^{\circ} 04^{\prime} 47.2^{\prime \prime} \\
\text { E } 47^{\circ} 22^{\prime} 14.2^{\prime \prime}\end{array}$ & 431 & 40 & $\begin{array}{l}\text { Sabkha, } \\
\text { Riyadh }\end{array}$ & $\begin{array}{l}\text { N } 25^{\circ} 14^{\prime} 28.2^{\prime \prime} \\
\text { E } 45^{\circ} 32^{\prime} 33.5^{\prime \prime}\end{array}$ & 645 \\
\hline 9 & $\begin{array}{l}\text { Sewage, } \\
\text { Riyadh }\end{array}$ & $\begin{array}{l}\text { N } 24^{\circ} 04^{\prime} 28.0^{\prime \prime} \\
\text { E } 47^{\circ} 22^{\prime} 11.3^{\prime \prime}\end{array}$ & 434 & 41 & $\begin{array}{l}\text { Sabkha, } \\
\text { Riyadh }\end{array}$ & $\begin{array}{l}\text { N } 25^{\circ} 14^{\prime} 00.7^{\prime \prime} \\
\text { E } 45^{\circ} 32^{\prime} 59.8^{\prime \prime}\end{array}$ & 646 \\
\hline 10 & $\begin{array}{l}\text { Sewage, } \\
\text { Riyadh }\end{array}$ & $\begin{array}{l}\mathrm{N} 24^{\circ} 11^{\prime} 10.0^{\prime \prime} \\
\mathrm{E} 47^{\circ} 26^{\prime} 03.3^{\prime \prime}\end{array}$ & 410 & 42 & $\begin{array}{l}\text { Sabkha, } \\
\text { Riyadh }\end{array}$ & $\begin{array}{l}\text { N } 25^{\circ} 13^{\prime} 50.7^{\prime \prime} \\
\text { E } 45^{\circ} 33^{\prime} 07.7^{\prime \prime}\end{array}$ & 648 \\
\hline 11 & $\begin{array}{l}\text { Sewage, } \\
\text { Riyadh }\end{array}$ & $\begin{array}{l}\text { N } 24^{\circ} 11^{\prime} 07.98^{\prime \prime} \\
\text { E } 47^{\circ} 25^{\prime} 58.41^{\prime \prime}\end{array}$ & 410 & 43 & $\begin{array}{l}\text { Sabkha, } \\
\text { Riyadh }\end{array}$ & $\begin{array}{l}\text { N } 25^{\circ} 13^{\prime} 03.1^{\prime \prime} \\
\text { E } 45^{\circ} 33^{\prime} 13.6^{\prime \prime}\end{array}$ & 669 \\
\hline 12 & $\begin{array}{l}\text { Sabkha, } \\
\text { Qassim }\end{array}$ & $\begin{array}{l}\text { N } 26^{\circ} 04^{\prime} 04.6^{\prime \prime} \\
\text { E } 44^{\circ} 09^{\prime} 58.5^{\prime \prime}\end{array}$ & 621 & 44 & $\begin{array}{l}\text { Sabkha, } \\
\text { Riyadh }\end{array}$ & $\begin{array}{l}\text { N } 25^{\circ} 21^{\prime} 09.07^{\prime \prime} \\
\text { E } 45^{\circ} 19^{\prime} 58.99^{\prime \prime}\end{array}$ & 671 \\
\hline 13 & $\begin{array}{l}\text { Sabkha, } \\
\text { Qassim }\end{array}$ & $\begin{array}{l}\text { N } 26^{\circ} 04^{\prime} 10.1^{\prime \prime} \\
\text { E } 44^{\circ} 09^{\prime} 59.9^{\prime \prime}\end{array}$ & 621 & 45 & $\begin{array}{l}\text { Sabkha, } \\
\text { Riyadh }\end{array}$ & $\begin{array}{l}\text { N } 25^{\circ} 14^{\prime} 02.5^{\prime \prime} \\
\text { E } 45^{\circ} 33^{\prime} 30.0^{\prime \prime}\end{array}$ & 646 \\
\hline 14 & $\begin{array}{l}\text { Sabkha, } \\
\text { Qassim }\end{array}$ & $\begin{array}{l}\mathrm{N} 26^{\circ} 03^{\prime} 51.9^{\prime \prime} \\
\mathrm{E} 44^{\circ} 01^{\prime} 41.2^{\prime \prime}\end{array}$ & 619 & 46 & $\begin{array}{l}\text { Sabkha, } \\
\text { Riyadh }\end{array}$ & $\begin{array}{l}\text { N } 25^{\circ} 14^{\prime} 10.3^{\prime \prime} \\
\text { E } 45^{\circ} 31^{\prime} 32.2^{\prime \prime}\end{array}$ & 651 \\
\hline 15 & $\begin{array}{l}\text { Sabkha, } \\
\text { Qassim }\end{array}$ & $\begin{array}{l}\text { N } 26^{\circ} 03^{\prime} 37.6^{\prime \prime} \\
\text { E } 44^{\circ} 09^{\prime} 39.0^{\prime \prime}\end{array}$ & 613 & 47 & $\begin{array}{l}\text { Sabkha, } \\
\text { Riyadh }\end{array}$ & $\begin{array}{l}\text { N } 25^{\circ} 16^{\prime} 07.6^{\prime \prime} \\
\text { E } 45^{\circ} 31^{\prime} 54.0^{\prime \prime}\end{array}$ & 644 \\
\hline 16 & $\begin{array}{l}\text { Sabkha, } \\
\text { Qassim }\end{array}$ & $\begin{array}{l}\mathrm{N} 26^{\circ} 03^{\prime} 16.9^{\prime \prime} \\
\mathrm{E} 44^{\circ} 09^{\prime} 54.3^{\prime \prime}\end{array}$ & 609 & 48 & $\begin{array}{l}\text { Sabkha, } \\
\text { Riyadh }\end{array}$ & $\begin{array}{l}\text { N } 25^{\circ} 20^{\prime} 31.4^{\prime \prime} \\
\text { E } 45^{\circ} 22^{\prime} 22.0^{\prime \prime}\end{array}$ & 655 \\
\hline 17 & $\begin{array}{l}\text { Sabkha, } \\
\text { Qassim }\end{array}$ & $\begin{array}{l}\text { N } 26^{\circ} 02^{\prime} 59.80^{\prime \prime} \\
\text { E } 44^{\circ} 10^{\prime} 02.86^{\prime \prime}\end{array}$ & 610 & 49 & $\begin{array}{l}\text { Sabkha, } \\
\text { Riyadh }\end{array}$ & $\begin{array}{l}\text { N } 25^{\circ} 20^{\prime} 13.5^{\prime \prime} \\
\text { E } 45^{\circ} 22^{\prime} 13.0^{\prime \prime}\end{array}$ & 662 \\
\hline
\end{tabular}




\begin{tabular}{|c|c|c|c|c|c|c|c|}
\hline 18 & $\begin{array}{l}\text { Sabkha, } \\
\text { Qassim }\end{array}$ & $\begin{array}{l}\text { N } 26^{\circ} 03^{\prime} 46.6^{\prime \prime} \\
\text { E } 44^{\circ} 08^{\prime} 28.1^{\prime \prime}\end{array}$ & 604 & 50 & $\begin{array}{l}\text { Sewage, } \\
\text { Riyadh }\end{array}$ & $\begin{array}{l}\text { N } 24^{\circ} 20^{\prime} 58.2^{\prime \prime} \\
\text { E } 046^{\circ} 55^{\prime} 49.9^{\prime \prime}\end{array}$ & 499 \\
\hline 19 & $\begin{array}{l}\text { Sabkha, } \\
\text { Qassim }\end{array}$ & $\begin{array}{l}\text { N } 26^{\circ} 03^{\prime} 44.3^{\prime \prime} \\
\text { E } 44^{\circ} 08^{\prime} 30.0^{\prime \prime}\end{array}$ & 605 & 51 & $\begin{array}{l}\text { Sewage, } \\
\text { Riyadh }\end{array}$ & $\begin{array}{l}\text { N } 24^{\circ} 22^{\prime} 02.9^{\prime \prime} \\
\text { E } 046^{\circ} 54^{\prime} 28.4^{\prime \prime}\end{array}$ & 505 \\
\hline 20 & $\begin{array}{l}\text { Sabkha, } \\
\text { Qassim }\end{array}$ & $\begin{array}{l}\text { N } 26^{\circ} 03^{\prime} 49.5^{\prime \prime} \\
\text { E } 44^{\circ} 08^{\prime} 13.6^{\prime \prime}\end{array}$ & 601 & 52 & $\begin{array}{l}\text { Sewage, } \\
\text { Riyadh }\end{array}$ & $\begin{array}{l}\mathrm{N} 24^{\circ} 22^{\prime} 16.5^{\prime \prime} \\
\mathrm{E} 46^{\circ} 54^{\prime} 20.8^{\prime \prime}\end{array}$ & 506 \\
\hline 21 & $\begin{array}{l}\text { Sabkha, } \\
\text { Qassim }\end{array}$ & $\begin{array}{l}\text { N } 26^{\circ} 03^{\prime} 46.1^{\prime \prime} \\
\text { E } 44^{\circ} 08^{\prime} 13.3^{\prime \prime}\end{array}$ & 602 & 53 & $\begin{array}{l}\text { Sewage, } \\
\text { Riyadh }\end{array}$ & $\begin{array}{l}\text { N } 24^{\circ} 21^{\prime} 58.8^{\prime \prime} \\
\text { E } 46^{\circ} 54^{\prime} 15.9^{\prime \prime}\end{array}$ & 506 \\
\hline 22 & $\begin{array}{l}\text { Sabkha, } \\
\text { Qassim }\end{array}$ & $\begin{array}{l}\text { N } 26^{\circ} 03^{\prime} 38.6^{\prime \prime} \\
\text { E } 44^{\circ} 08^{\prime} 07.8^{\prime \prime}\end{array}$ & 604 & 54 & $\begin{array}{l}\text { Sewage, } \\
\text { Riyadh }\end{array}$ & $\begin{array}{l}\text { N } 24^{\circ} 21^{\prime} 48.7^{\prime \prime} \\
\text { E } 46^{\circ} 54^{\prime} 20.4^{\prime \prime}\end{array}$ & 506 \\
\hline 23 & $\begin{array}{l}\text { Sabkha, } \\
\text { Qassim }\end{array}$ & $\begin{array}{l}\text { N } 26^{\circ} 03^{\prime} 33.6^{\prime \prime} \\
\text { E } 44^{\circ} 08^{\prime} 18.6^{\prime \prime}\end{array}$ & 603 & 55 & $\begin{array}{l}\text { Sewage, } \\
\text { Riyadh }\end{array}$ & $\begin{array}{l}\text { N } 24^{\circ} 21^{\prime} 31.9^{\prime \prime} \\
\text { E } 46^{\circ} 54^{\prime} 31.1^{\prime \prime}\end{array}$ & 502 \\
\hline 24 & $\begin{array}{l}\text { Sabkha, } \\
\text { Qassim }\end{array}$ & $\begin{array}{l}\text { N } 26^{\circ} 03^{\prime} 26.7^{\prime \prime} \\
\text { E } 44^{\circ} 08^{\prime} 20.7^{\prime \prime}\end{array}$ & 604 & 56 & $\begin{array}{l}\text { Sewage, } \\
\text { Riyadh }\end{array}$ & $\begin{array}{l}\text { N } 24^{\circ} 18^{\prime} 36.35^{\prime \prime} \\
\text { E } 46^{\circ} 58^{\prime} 40.14^{\prime \prime}\end{array}$ & 501 \\
\hline 25 & $\begin{array}{l}\text { Sabkha, } \\
\text { Qassim }\end{array}$ & $\begin{array}{l}\text { N } 26^{\circ} 03^{\prime} 22.3^{\prime \prime} \\
\text { E } 44^{\circ} 08^{\prime} 22.3^{\prime \prime}\end{array}$ & 604 & 57 & $\begin{array}{l}\text { Sewage, } \\
\text { Riyadh }\end{array}$ & $\begin{array}{l}\text { N } 24^{\circ} 23^{\prime} 01.1^{\prime \prime} \\
\text { E } 046^{\circ} 49^{\prime} 45.0^{\prime \prime}\end{array}$ & 564 \\
\hline 26 & $\begin{array}{l}\text { Sabkha, } \\
\text { Qassim }\end{array}$ & $\begin{array}{l}\text { N } 26^{\circ} 02^{\prime} 51.39^{\prime \prime} \\
\text { E } 44^{\circ} 08^{\prime} 42.48^{\prime \prime}\end{array}$ & 605 & 58 & $\begin{array}{l}\text { Sewage, } \\
\text { Riyadh }\end{array}$ & $\begin{array}{l}\text { N } 24^{\circ} 22^{\prime} 31.8^{\prime \prime} \\
\text { E } 46^{\circ} 49^{\prime} 53.3^{\prime \prime}\end{array}$ & 566 \\
\hline 27 & $\begin{array}{l}\text { Sabkha, } \\
\text { Qassim }\end{array}$ & $\begin{array}{l}\text { N } 26^{\circ} 02^{\prime} 26.6^{\prime \prime} \\
\text { E } 44^{\circ} 08^{\prime} 13.2^{\prime \prime}\end{array}$ & 610 & 59 & $\begin{array}{l}\text { Sewage, } \\
\text { Riyadh }\end{array}$ & $\begin{array}{l}\text { N } 24^{\circ} 22^{\prime} 11.6^{\prime \prime} \\
\text { E } 046^{\circ} 50^{\prime} 23.8^{\prime \prime}\end{array}$ & 559 \\
\hline 28 & $\begin{array}{l}\text { Sabkha, } \\
\text { Qassim }\end{array}$ & $\begin{array}{l}\mathrm{N} 26^{\circ} 02^{\prime} 21.8^{\prime \prime} \\
\mathrm{E} 44^{\circ} 08^{\prime} 45.8^{\prime \prime}\end{array}$ & 599 & 60 & $\begin{array}{l}\text { Sewage, } \\
\text { Qassim }\end{array}$ & $\begin{array}{l}\text { N } 25^{\circ} 56^{\prime} 04.4^{\prime \prime} \\
\text { E } 43^{\circ} 28^{\prime} 22.3^{\prime \prime}\end{array}$ & 650 \\
\hline 29 & $\begin{array}{l}\text { Sabkha, } \\
\text { Qassim }\end{array}$ & $\begin{array}{l}\text { N } 26^{\circ} 00^{\prime} 27.81^{\prime \prime} \\
\text { E } 44^{\circ} 09^{\prime} 16.58^{\prime \prime}\end{array}$ & 600 & 61 & $\begin{array}{l}\text { Sewage, } \\
\text { Qassim }\end{array}$ & $\begin{array}{l}\text { N } 25^{\circ} 56^{\prime} 06.8^{\prime \prime} \\
\text { E } 43^{\circ} 28^{\prime} 27.1^{\prime \prime}\end{array}$ & 650 \\
\hline 30 & $\begin{array}{l}\text { Sabkha, } \\
\text { Qassim }\end{array}$ & $\begin{array}{l}\text { N } 25^{\circ} 58^{\prime} 48.0^{\prime \prime} \\
\text { E } 44^{\circ} 10^{\prime} 14.9^{\prime \prime}\end{array}$ & 602 & 62 & $\begin{array}{l}\text { Sewage, } \\
\text { Qassim }\end{array}$ & $\begin{array}{l}\text { N } 25^{\circ} 54^{\prime} 33.3^{\prime \prime} \\
\text { E } 43^{\circ} 26^{\prime} 26.9^{\prime \prime}\end{array}$ & 649 \\
\hline 31 & $\begin{array}{l}\text { Sabkha, } \\
\text { Qassim }\end{array}$ & $\begin{array}{l}\text { N } 25^{\circ} 58^{\prime} 00.7^{\prime \prime} \\
\text { E } 44^{\circ} 10^{\prime} 47.7^{\prime \prime}\end{array}$ & 604 & 63 & $\begin{array}{l}\text { Sewage, } \\
\text { Qassim }\end{array}$ & $\begin{array}{l}\text { N } 25^{\circ} 54^{\prime} 07.8^{\prime \prime} \\
\text { E } 43^{\circ} 27^{\prime} 24.2^{\prime \prime}\end{array}$ & 647 \\
\hline 32 & $\begin{array}{l}\text { Sabkha, } \\
\text { Qassim }\end{array}$ & $\begin{array}{l}\text { N } 25^{\circ} 58^{\prime} 58.3^{\prime \prime} \\
\text { E } 44^{\circ} 11^{\prime} 30.5^{\prime \prime}\end{array}$ & 607 & & & & \\
\hline
\end{tabular}

Appendix 2. Collected plant species and their families, lifeforms and chorotype

\begin{tabular}{l|l|l|c}
\hline \multicolumn{1}{c|}{ Species } & \multicolumn{1}{|c|}{ Families } & \multicolumn{1}{c}{ Lifeform } & Chorotype* \\
& & & \\
\hline Acacia ehrenbergiana & Leguminosae & Shrub & SH-SM \\
Acacia gerrardii & Leguminosae & Tree & SH-SM \\
Acacia raddiana & Leguminosae & Tree & SH-SM \\
Aeluropus lagopoides & Gramineae & Perennial grass & Eu. Sib-Med-IT \\
Aizoon canariense & Aizoaceae & Annual herb & SA-SM \\
Alhagi graecorum & Leguminosae & Perennial shrub & MED-IT \\
Amaranthus viridis & Amaranthaceae & Annual herb & TR \\
Anisosciadium lanatum & Umbelliferae & Annual herb & SA \\
Anvillea garcinii & Compositae & Perennial shrub & SA \\
Artemisia monosperma & Chenopodiaceae & Shrub & SA \\
Asphoedelus tenuifolius & Asphodelaceae & Annual herb & SA-SM \\
Atriplex suberecta & Chenopodiaceae & Perennial shrub & Am \\
Atrriplex leucoclada & Chenopodiaceae & Shrub & SA \\
Bassia eriophora & Chenopodiaceae & Annual herb & SA-IT \\
Bassia muricata & Chenopodiaceae & Annual herb & SA-IT \\
Cakile arabica & Cruciferae & Annual herb & SA \\
Calotropis procera & Asclepiadaceae & Shrub & SM \\
Capparis spinosa & Capparaceae & Shrub & Med-SA \\
Centropodium forsskallii & Gramineae & Perennial grass & SA-IT \\
Chenopodium album & Chenopodiaceae & Annual herb & PALEO \\
Chenopodium ambrosioides & Chenopodiaceae & Perennial shrub & TR \\
Chenopodium glaucum & Chenopodiaceae & Annual herb & EU-MED \\
Chenopodium murale & Chenopodiaceae & Annual herb & PALEO \\
Chrozophora oblongifolia & Euphorbiaceae & Perennial shrub & IT \\
\hline
\end{tabular}




\begin{tabular}{|c|c|c|c|}
\hline Species & Families & Lifeform & Chorotype* \\
\hline Cistache tubulosa & Orobanchaceae & Annual herb & SA-IT \\
\hline Citrullus colocynthis & Cucurbitaceae & Annual herb & SA \\
\hline Cleome amblyocarpa & Capparaceae & Annual herb & SA-SM \\
\hline Cleome rupicola & Capparaceae & Annual herb & SH-SM \\
\hline Convolvulus austro-aegyptiacus & Convolvulaceae & Perennial shrub & SA \\
\hline Cornulaca monacantha & Chenopodiaceae & Perennial shrub & SA \\
\hline Cressa cretica & Convolvulaceae & Annual herb & MED-IT \\
\hline Cynodon dactylon & Gramineae & Perennial grass & TR \\
\hline Datura innoxia & Solanaceae & Shrub & AM \\
\hline Devera triradiata & Umbelliferae & Shrub & $\mathrm{SA}$ \\
\hline Dipterygium glaucum & Capparaceae & Perennial shrub & SA \\
\hline Emex spinosa & Polygonaceae & Annual herb & MED-SA \\
\hline Ephedra aphylla & Ephedraceae & Shrub & SA \\
\hline Eragrostis barrelieri & Gramineae & Perennial grass & MED-SA \\
\hline Eremobium lineare & Cruciferae & Annual herb & SA \\
\hline Fagonia bruguieri & Zygophyllaceae & Perennial shrub & SA \\
\hline Fagonia indica & Zygophyllaceae & Perennial shrub & SA \\
\hline Farsetia longisiliqua & Cruciferae & Perennial shrub & SA \\
\hline Frankenia pulverulenta & Frankeniaceae & Annual herb & Eu-Sib-Med-IT \\
\hline Gisekia pharnaceoides & Molluginaceae & Annual herb & TR \\
\hline Gypsophila capillaris & Caryophyllaceae & Annual herb & IT \\
\hline Halothamnus iraqensis & Chenopodiaceae & Perennial shrub & SA-IT \\
\hline Haloxylon salicornicum & Chenopodiaceae & Perennial shrub & SA \\
\hline Helianthemum lippii & Cistaceae & Perennial shrub & SA-SM \\
\hline Heliotropium bacciferum & Boraginaceae & Perennial shrub & SA-SH \\
\hline Heliotropium digynum & Boraginaceae & Perennial shrub & SA \\
\hline Juncus rigidus & Juncaceae & Perennial shrub & SA-IT \\
\hline Lactuca serriola & Compositae & Perennial shrub & Med-Eu-Sib-IT \\
\hline Lasiurus scindicus & Gramineae & Perennial grass & SA-SH-SM \\
\hline Launaea capitata & Compositae & Annual herb & SA \\
\hline Launaea mucronata & Compositae & Annual herb & SA \\
\hline Launaea nudicaulis & Compositae & Annual herb & SA \\
\hline Leptadenia pyrotechnica & Asclepiadaceae & Shrub & SA-SM \\
\hline Leptochloa fusca & Poaceae & Perennial grass & TR \\
\hline Lolium rigidum & Gramineae & Annual grass & MED-IT \\
\hline Lycium shawii & Solanaceae & Shrub & SA \\
\hline Malva parviflora & Malvaceae & Annual herb & MED-IT \\
\hline Moltkiopsis ciliata & Boraginaceae & Perennial shrub & SA \\
\hline Neurada procumbens & Neuradaceae & Annual herb & SA \\
\hline Ochthochloa compressa & Gramineae & Perennial grass & SA-SM \\
\hline Ochradenus baccatus & Resedaceae & Shrub & SH-SM-SA \\
\hline Oligomeris linifolia & Resedaceae & Annual herb & SH-SM-SA \\
\hline Panicum turgidum & Gramineae & Perennial grass & SH-SM-SA \\
\hline Paspalidium desertorum & Gramineae & Annual grass & SH-SM \\
\hline Pennisetum divisum & Gramineae & Perennial grass & SA \\
\hline Picris babylonica & Compositae & Annual herb & SA \\
\hline Phalaris minor & Gramineae & Annual grass & MED-IT \\
\hline Phragmites australis & Gramineae & Perennial grass & MED-IT-SA \\
\hline Plantago amplexicaulis & Plantaginaceae & Annual herb & $\mathrm{SA}$ \\
\hline Plantago boissieri & Plantaginaceae & Annual herb & SA \\
\hline Polycarpaea repens & Caryophyllaceae & Perennial shrub & SA-SM \\
\hline Polygonum argyrocoleum & Polygonaceae & Annual herb & MED-IT \\
\hline Polypogon monsepeliensis & Gramineae & Annual grass & Med-IT-SA \\
\hline Portulaca oleracea & Portulacaceae & Annual herb & COSM \\
\hline Prosopis fracta & Leguminosae & Perennial shrub & IT \\
\hline
\end{tabular}




\begin{tabular}{|c|c|c|c|}
\hline Species & Families & Lifeform & Chorotype* \\
\hline Prosopis juliflora & Leguminosae & Tree & $\mathrm{AM}$ \\
\hline Pulicaria undulata & Compositae & Perennial shrub & SA-SM \\
\hline Reseda arabica & Resedaceae & Annual herb & SA \\
\hline Rhazya stricta & Apocynaceae & Perennial shrub & SA \\
\hline Ricinus communis & Euphorbiaceae & Shrub & $\mathrm{TR}$ \\
\hline Rumex dentaus & Polygonaceae & Perennial shrub & Med-Eu-Sib-IT \\
\hline Ruppia maritima & Ruppiaceae & Perennial shrub & TR \\
\hline Salicornia europaea & Chenopodiaceae & Annual herb & Med-Eu.Sib \\
\hline Salsola imbricata & Chenopodiaceae & Perennial shrub & SA-SH \\
\hline Salvia spinosa & Labiatae & Annual herb & IT \\
\hline Savignya parviflora & Cruciferae & Annual herb & SA \\
\hline Schismus barbatus & Gramineae & Annual grass & SA-IT \\
\hline Sclerocephalus arabicus & Caryophyllaceae & Perennial shrub & SA \\
\hline Scorzonera intricata & Compositae & Perennial shrub & IT \\
\hline Seidletzia rosmarinus & Chenopodiaceae & Shrub & SA \\
\hline Senna italica & Leguminosae & Perennial shrub & SH-SM \\
\hline Sonchus oleraceus & Compositae & Annual herb & Eu-Sib-Medi-IT \\
\hline Spergularia diandra & Caryophyllaceae & Annual herb & Med-IT-Eu.sib \\
\hline Stipagrostis plumosa & Gramineae & Perennial grass & SA-IT \\
\hline Suaeda aegyptiaca & Chenopodiaceae & Annual herb & SA \\
\hline Suaeda vermiculata & Chenopodiaceae & Perennial shrub & SA \\
\hline Tamarix aphylla & Tamaricaceae & Tree & SA-SM \\
\hline Tamarix aucheriana & Tamaricaceae & Shrub & SA-SM \\
\hline Tamarix nilotica & Tamaricaceae & Shrub & SA \\
\hline Traganum nudatum & Chenopodiaceae & Perennial shrub & SA \\
\hline Xanthium strumarium & Compositae & Perennial shrub & TR \\
\hline Zilla spinosa & Cruciferae & Annual herb & SA \\
\hline Zygophyllum coccineum & Zygophyllaceae & Perennial shrub & SA \\
\hline Zygophyllum propinquum ssp. migahidii & Zygophyllaceae & Perennial shrub & SA \\
\hline Zygophyllum simplex & Zygophyllaceae & Annual herb & SH-SM \\
\hline
\end{tabular}

* TR: Tropical, SH-SM: Sahel-Somalia Masai, SA-SM: Saharo Arabian-Somalia Masai, SA-SH-SM: Saharo Arabian-Sahel-Somalia Masai, SA-IT: Saharo Arabian-Irano Turanian, SA: Saharo Arabian, Paleo: Paleotropic, Med-SA: Mediterranean-Saharo Arabian, MED-IT-SA: Mediterranean-Irano Turanian-Saharo Arabian, MED-IT: Mediterranean-Irano Turanian, IT: Irano Turanian, Eu-Sib-MedIT: Euro Siberian-Mediterranean-Irano Turanian, COSM: Cosmopolitan, Am: American 